\title{
Table of international treaties and other international instruments
}

1946 International Convention for the Regulation of Whaling, opened for signature 2 December 1946, 161 UNTS 72 (entered into force 10 November 1948) 4

1947 General Agreement on Tariffs and Trade, opened for signature 30 October 1947, 55 UNTS 187 (in force provisionally under the Protocol of Application, 55 UNTS 308) 8, 27

1958 Convention on the High Seas, opened for signature 29 April 1958, (1958) 450 UNTS 82 (entered into force 30 September 1962) 205-6

1966 International Covenant on Civil and Political Rights, opened for signature 16 December 1966, 999 UNTS 171 (entered into force 23 March 1976) 79 International Covenant on Economic, Social and Cultural Rights, opened for signature 16 December 1966, 999 UNTS 3 (entered into force 3 January 1976) 79-81
1969 Vienna Convention on the Law of Treaties, opened for signature 23 May 1969, 1155 UNTS 332 (entered into force 27 January 1980) 96

1971 Convention on Wetlands of International Importance, Especially as Waterfowl Habitat, opened for signature 2 February 1971, 996 UNTS 245 (entered into force 21 December 1975) 125

1972 Convention on the Prevention of Marine Pollution by Dumping of Wastes and Other Materials, opened for signature 29 December 1972, 1046 UNTS 120 (entered into force 30 August 1975) 25, 195-6, 205-25, 229, 236, 239, 242, 244

Declaration of the United Nations Conference on the Human Environment, UN Doc A/CONF.48/14/Rev.1 (1972) 4-5, 9, 11, 12, 107, 115, 116, 123, 141, 142, 144, 145, 146, 235, 248 
1973 Convention on International

Trade in Endangered Species

of Wild Fauna and Flora, opened for signature 3

March 1973, 993 UNTS 243

(entered into force 1 July 1975) 6

1976 Convention concerning Minimum Age for Admission to Employment, opened for signature 26 June 1973, 1015 UNTS 297 (entered into force 19 June 1976) 80

1977 Treaty Concerning the Construction and Operation of the GabčikovoNagymaros System of Locks, opened for signature 16 September 1977 (1993) 32 ILM 1247 (entered into force 30 June 1978) 121

1979 Convention on Long-Range Transboundary Air Pollution, opened for signature 13 November 1979, 1302 UNTS 218 (entered into force 16 March 1983) 167

Convention on the Conservation of Migratory Species of Wild Animals, opened for signature 23 June 1979, (1980) 19 ILM 15 (entered into force 1 November 1983) 6

1982 United Nations Convention on the Law of the Sea, opened for signature 10 December 1982, 1833 UNTS 397 (entered into force 16 November 1994) viii, 206, 208-209, 211

World Charter for Nature, UN GAOR, GA Res 37/7, 48th plen mtg, UN Doc A/ RES/37/7 (1982) $\mathbf{5}$

1985 Vienna Convention for the Protection of the Ozone Layer, opened for signature 22 March 1985, 1513 UNTS 324 (entered into force 22 September 1988) 199

1986 Protocol for the Prevention of Pollution of the South Pacific Region by Dumping, opened for signature 25

November 1986 (1987) 1982 UNTS 4 (entered into force 22 August 1990) 206

1987 Montreal Protocol on Substances that Deplete the Ozone Layer, opened for signature 16 September 1987, 1522 UNTS 3 (entered into force 1 January 1989) 199

1988 Convention on the Regulation of Antarctic Mineral Resource Activities, opened for signature 25 November 1988, (1988) 27 ILM 868 (not yet in force) $\mathbf{2 4 6}$

1989 Basel Convention on the Control of Transboundary Movements of Hazardous Wastes and Their Disposal, opened for signature 22 March 1989, 1673 UNTS 126 (entered into force 24 May 1992) 6 
1991 Protocol on Environmental

Protection to the Antarctic

Treaty, opened for

signature 4 October 1991,

(1991) 30 ILM 1461

(entered into force 14

January 1998) 6

1992 United Nations Declaration on Environment and

Development, UN Doc A/

CONF.151/5/Rev.1

(1992) 59, 107, 164, 235

Agenda 21, UN Doc A/

CONF.151/26/Rev.1

(1992) 164, 166, 187,

192

Convention of the Protection

and Use of Transboundary

Watercourses and

International Lakes, opened

for signature $17 \mathrm{March}$

1992, 31 ILM 1312 (entered

into force 6 October

1996) 167

Convention on Biological

Diversity, opened for

signature 5 June 1992, 1760

UNTS 143 (entered into

force 29 December

1993) 96

United Nations Framework

Convention on Climate

Change, opened for

signature 9 May 1992, 1771

UNTS 107 (entered into

force 21 March 1994) 92, 199

1993 Special Agreement between the Republic of Hungary and the Slovak Republic for

Submission to the

International Court of
Justice of the Differences

between them concerning the

Gabčíkovo-Nagymaros

Project, opened for

signature 7 April 1993,

(1993) 32 ILM 1293

(entered into force 28 June

1993) 121

1994 Convention on Cooperation

for the Protection and

Sustainable Use of the

Danube, opened for

signature 29 June 1994 ,

(1996) 19 International

Environment Reports 997

(entered into force 22

October 1998) 125

1996 Protocol to the Convention

on the Prevention of Marine

Pollution by Dumping of

Wastes and Other Matter,

opened for signature 7

November 1996 (1997) 36

ILM 1 (entered into force

24 March 2006) 25, 195-6,

207-29, 236, 239, 242, 244,

247

1997 United Nations Convention

on the Law of Non-

Navigational Uses of

International Watercourses,

opened for signature 21

May 1997, (1997) 36 ILM

700 (not in force) $\mathbf{1 3 3}$

1998 Convention for the

Protection of the Marine

Environment of the North-

East Atlantic, opened for

signature 22 September

1992, 31 ILM 1069 (entered

into force on $25 \mathrm{March}$

1998) 167 
2001 Draft Articles on

Responsibility of States for

Internationally Wrongful

Acts, Report of the

International Law

Commission, 53rd Session,

UN Doc A/56/10 (2001)

(noted in GA Res 56/83,

UN Doc A/RES/56/83

(2001) 142

Draft Articles on the

Prevention of

Transboundary Harm from

Hazardous Activities,

Report of the International

Law Commission, 53rd

Session, UN Doc A/56/10

(2001) 142, 144-8

The OECD Guidelines for

Multinational Enterprises:

Text, Commentary and

Clarifications, OECD Doc.

DAFFE/IME/

WPG(2000)15/FINAL (31

October 2001) 10, 168
Stockholm Convention on

Persistent Organic

Pollutants, opened for

signature 22 May 2001,

40 ILM 532 (entered

into force 17 May

2004) 7

International Convention on the Control of Harmful Anti-fouling Systems on

Ships, opened for signature

5 October 2001, 40 ILM

532 (2001) (entered into force 17 September

2008) 7

2003 Norms on the

Responsibilities of

Transnational

Corporations and Other

Business Enterprises with

Regard to Human Rights,

UN ESCOR, 55th sess,

Agenda Item 4 UN Doc E/

CN.4/Sub.2/2003/12/Rev.2

(2003) 5 